\title{
Improving Anaerobic Methane Production from Ammonium-rich Piggery Waste in a Zeolite-fixed Bioreactor and Evaluation of Ammonium Adsorbed on Zeolite A-3 as Fertilizer
}

\author{
Cang Yư ${ }^{1}$, Dawei $\mathrm{Li}^{1}$, Qinghong Wang${ }^{2}$, Zhenya Zhang ${ }^{1, *}$ and Yingnan Yang ${ }^{1, *}$ \\ ${ }^{1}$ Graduate School of Life and Environmental Science, University of Tsukuba, 1-1-1 Tennodai, Tsukuba, Ibaraki 305-8572, Japan \\ ${ }^{2}$ State Key Laboratory of Heavy Oil Processing, China University of Petroleum, Changping, Beijing 102249, China
}

\begin{abstract}
To mitigate ammonia inhibition and enhance methane production, a zeolite-fixed bioreactor was developed for anaerobic digestion of ammonium-rich piggery wastes. Ammonium adsorption on zeolite A-3 fitted with the pseudo-second-order kinetic model and can be described by both Langmuir and Freundlich isotherms. Desorption of ammonium from saturated zeolite fits the first-order reversible reaction kinetic. The zeolite-fixed bioreactor with zeolite loading rate of $10 \mathrm{~g} \mathrm{l}-1$ showed the shortest startup period of 13 days and achieved the highest methane yield of $354.2 \mathrm{ml} \mathrm{g-1-VS}$ and the largest COD removal rate of $75.37 \%$. Due to the effective mitigation of ammonia inhibition and enhancement of methane production, zeolite-fixed bioreactor is a good option for practical anaerobic digestion of ammonium-rich piggery wastes. Ammonium saturated zeolite can be directly used as fertilizer to decrease annual production of nitrogen fertilizer. Besides, regeneration of zeolite using $\mathrm{Na} 2 \mathrm{SO} 4$ solution also obtained a (NH4)2SO4 by-product, which is nice nitrogenous fertilizer.
\end{abstract}

Keywords: Anaerobic digestion; Piggery wastes; Ammonium inhibition; Zeolite-fixed bioreactor

\section{Introduction}

In the past decades, anaerobic digestion of piggery wastes has attracted considerable attention because of the bioenergy recovery in the form of methane and mitigation of environment pollution [1]. However, digestion of pure piggery wastes has been observed to be unsuccessful, due to the inhibition of ammonia produced during biodegradation of nitrogenous compounds such as proteins and amino acids $[2,3]$. Although ammonia is an essential nutrient for growth of microorganisms [4], its undissociated form at high concentration has potential toxicity to methanogens [2]. Hobson and Shaw [5] reported that ammonium concentration of $2500 \mathrm{mg} \mathrm{NH}_{4}^{+}-\mathrm{N} \mathrm{l}^{-1}$ resulted to partial inhibition of methane production, while a complete failure of methanogenesis occurred whe $\mathrm{n}$ the concentration up to 3300 $\mathrm{mg} \mathrm{NH} 4+\mathrm{N} \mathrm{l}^{-1}$. Consequently, to improve methane production from ammonium-rich piggery wastes, it is necessary to mitigate ammonia inhibition in the anaerobic digestion process using effective techniques.

Many physicochemical and biological methods have been employed for alleviating ammonia inhibition, such as air stripping [6], adsorption [7], chemical precipitation [8], microorganisms acclimation [9] and co-digestion [10]. Among these methods, adsorption has drawn more attention because of its in-situ ammonia removal, easy operation, high safety and low cost. Comparing with activated carbon [11], fly ash [12] and activated alumina [13], zeolite is the most promising adsorbent for ammonia removal [14] owing to its porous structure, biochemical stability and abundance on the earth. On the other hand, zeolite seems to be a potential support material for the immobilization of microorganisms as a porous surface. These characteristics make zeolite a promising option for counteracting ammonia inhibition in the anaerobic digestion of ammonium-rich piggery wastes.

In recent years, effects of variety, particle size, doses and dosage procedure of zeolite addition on anaerobic digestion of piggery wastes have been investigated [15-17]. Kotsopoulos et al. [18] showed that adding natural zeolite increased methane production from piggery wastes by reducing the toxicity of ammonia and regulating the $\mathrm{C} / \mathrm{N}$ (carbon/nitrogen) ratio through ammonia adsorption. Zeolite addition in anaerobic digestion of piggery wastes achieved the maximum ammonia removal at a dosage of 0.10 g-zeolite $\mathrm{g}^{-1}$-VSS, regardless of particles sized [16]. Milán et al. [15] found that addition of natural zeolite (doses: 2-4 $\mathrm{g} \mathrm{l}^{-1}$ ) contributed to enhance the anaerobic digestion of piggery wastes by reducing the inhibitory effect of ammonia, but inhibition could not be overcome at doses higher than $6 \mathrm{gl}^{-1}$. Continuous anaerobic digestion of piggery wastes in terms of chemical oxygen demand (COD) removal efficiency and methane production was effectively promoted by addition of natural zeolite on a daily basis [19]. According to these previous studies, addition of zeolite at an appropriate dosage could effectively mitigate ammonia inhibition thereby enhance the methane production from piggery wastes. However, the enhanced methane production was only attributed to ammonium removal by zeolite, neither the immobilization of microorganism nor the fixed mode of zeolite for mitigating ammonia inhibition were investigated in all of these studies. On the other hand, ammonium desorption by using brine solution [20] is of great significance for nitrogen recovery and sustainable utilization of zeolite in the anaerobic digestion of ammonium-rich piggery wastes. Nevertheless, when using zeolite as an additive to migrate ammonia inhibition in the anaerobic digestion of

*Corresponding author: Yingnan Yang, Graduate School of Life and Environmental Science, University of Tsukuba, 1-1-1 Tennodai, Tsukuba, Ibaraki 305-8572, Japan, Tel/Fax: +81-29-853-4650; Fax: +6088320348; E-mail: yo.innan.fu@u.tsukuba.ac.jp

Zhenya Zhang, Graduate School of Life and Environmental Science, University of Tsukuba, 1-1-1 Tennodai, Tsukuba, Ibaraki 305-8572, Japan, Tel/Fax: +81-29-8534650; E-mail: zhang.zhenya.fu@u.tsukuba.ac.jp

Received September 17, 2014; Accepted October 20, 2014; Published Octobe 24, 2014

Citation: Yu C, Li D, Wang Q, Zhang Z, Yang Y (2014) Improving Anaerobic Methane Production from Ammonium-rich Piggery Waste in a Zeolite-fixed Bioreactor and Evaluation of Ammonium Adsorbed on Zeolite A-3 as Fertilizer. Int J Waste Resources 4: 160. doi: 10.4172/2252-5211.1000160

Copyright: @ 2014 Yu C, et al. This is an open-access article distributed unde the terms of the Creative Commons Attribution License, which permits unrestricted use, distribution, and reproduction in any medium, provided the original author and source are credited. 
Citation: Yu C, Li D, Wang Q, Zhang Z, Yang Y (2014) Improving Anaerobic Methane Production from Ammonium-rich Piggery Waste in a Zeolite-fixed Bioreactor and Evaluation of Ammonium Adsorbed on Zeolite A-3 as Fertilizer. Int J Waste Resources 4: 160. doi: $10.4172 / 2252-5211.1000160$

Page 2 of 8

piggery wastes, the ammonium desorption from zeolite had never been concerned by the previous researchers.

In this work, a zeolite-fixed bioreactor with advantages of ammonia adsorption and desorption of the adsorbed ammonium as fertilizer for future using and microorganism immobilization was developed for the anaerobic digestion of ammonium-rich piggery wastes. The purposes of this study are to investigate (1) the adsorption mechanism of ammonium on zeolite A-3 by kinetic and isotherm analyses; (2) the desorption efficiency of ammonium from zeolite A-3 in sodium sulfate solution; (3) the performance of zeolite-fixed bioreactor for ammonia removal and microorganism immobilization during anaerobic digestion of ammonium-rich piggery wastes.

\section{Materials and Methods}

\section{Piggery wastes and seed sludge}

Ammonium-rich piggery wastes used in the experiment was stale manure that had been kept at room temperature for almost two years after it had been obtained from a pig farm located in Tokyo. The stale manure compared with fresh piggery waste has a higher concentration of ammonium which can reach levels of up to $22,310 \mathrm{mg} \mathrm{l}^{-1}$. The piggery waste was inoculated with $25 \%$ sludge $(\mathrm{w} / \mathrm{w})$ after diluted with tap water and $\mathrm{pH}$ adjustment with $\mathrm{HCl}$. General characteristics of the diluted substrate were: COD: $76700 \mathrm{mg} \mathrm{l}^{-1}$, total nitrogen (TN): 9400 $\mathrm{mg} \mathrm{l}^{-1}$, total solid (TS): $35000 \mathrm{mg} \mathrm{l}^{-1}$, volatile solid (VS): $27725 \mathrm{mg} \mathrm{l}^{-1}$, $\mathrm{NH}_{4}^{+}-\mathrm{N}: 3770 \mathrm{mg} \mathrm{l}^{-1}$ and $\mathrm{pH}: 7.2$.

The digested sludge collected from a municipal wastewater treatment plant in Ibaraki, Japan was used as seed sludge. After it was collected, the digested sludge was storage under $4^{\circ} \mathrm{C}$ in a refrigerator. Before used as inoculums, $900 \mathrm{ml}$ digested sludge was cultured by putting into a fermenter bottle $(1000 \mathrm{ml})$. After two days, $2 \mathrm{~g}$ raw piggery wastes was added to this reactor every day until the methane concentration reached $80 \%$ approximately. The cultivation of methanogens was carried out at $35^{\circ} \mathrm{C}$ for 7 days. The characteristics of seed sludge were: COD: $6500 \mathrm{mg} \mathrm{l}^{-1}$, TN: $5489 \mathrm{mg} \mathrm{l}^{-1}$, TS: $9850 \mathrm{mg} \mathrm{l}^{-1}$, VS: $7415 \mathrm{mg} \mathrm{l}^{-1}, \mathrm{NH}_{4}^{+}-\mathrm{N}$ : $1547 \mathrm{mg} \mathrm{l}^{-1}, \mathrm{pH}: 7.1$.

\section{Zeolite}

The artificial zeolite A-3 used for ammonium adsorption and microorganism immobilization in the experiments was provided by Wako Pure Chemical Industries, Ltd. It has the following characteristics: pore diameter $(\AA): 3$, Particle size $(\mathrm{mm}): 2.36-4.75$, absorbable molecule: $\mathrm{H}_{2} \mathrm{O}, \mathrm{NH}_{3}, \mathrm{He}$, unabsorbable molecule: $\mathrm{CH}_{4}$, $\mathrm{CO}_{2}, \mathrm{C}_{2} \mathrm{H}_{2}, \mathrm{O}_{2}, \mathrm{H}_{2} \mathrm{~S}, \mathrm{C}_{2} \mathrm{H}_{5} \mathrm{OH}$, Water absorbing capacity (wt \%): 20 , General formula: $(0.4 \mathrm{~K}+0.6 \mathrm{Na})_{2} \mathrm{O} \cdot \mathrm{Al}_{2} \mathrm{O}_{3} \cdot 2 \mathrm{SiO}_{2}$.

\section{Ammonium adsorption experiment}

The experiments of ammonium adsorption on zeolite A-3 were carried out in batch mode. For the ammonium nitrogen adsorption experiments and analysis, ammonium solution with a certain concentration ranging from 1000 to $5000 \mathrm{mg} \mathrm{l}^{-1}$ was prepared immediately by dissolving $\mathrm{NH}_{4} \mathrm{Cl}$ in deionized water. Zeolite A-3 was added into $50 \mathrm{ml} \mathrm{NH}_{4} \mathrm{Cl}$ solution at a loading rate of $10 \mathrm{~g} \mathrm{l}^{-1}$ in a triangular flask $(100 \mathrm{ml})$. Then, continuously shaking $(100 \mathrm{rpm})$ of the triangular flasks were conducted in a constant temperature shaker with water bath at $35^{\circ} \mathrm{C}$ for $24 \mathrm{~h}$.

\section{Ammonium desorption experiment}

For nitrogen recovery in the form of ammonium sulfate $\left(\left(\mathrm{NH}_{4}\right)_{2} \mathrm{SO}_{4}\right)$ which is a nice nitrogenous fertilizer, desorption of ammonium from saturated zeolite A-3 were performed in sodium sulfate solution. According to the ion equivalent exchange principle: $2 \mathrm{NH}_{4}^{+}-$zeolite + $\mathrm{Na}_{2} \mathrm{SO}_{4}=2 \mathrm{Na}^{+}$-zeolite $+\left(\mathrm{NH}_{4}\right)_{2} \mathrm{SO}_{4}$, the calculated concentration of $\mathrm{Na}_{2} \mathrm{SO}_{4}$ solution was $7.1 \mathrm{~mol} \mathrm{l}^{-1}$ for the ammonium desorption from 0.5 g saturated zeolite A-3 (adsorbed $\mathrm{NH}_{4}^{+}-\mathrm{N}$ : $20 \mathrm{mg}$ ). In the ammonium desorption experiment, $0.5 \mathrm{~g}$ of saturated zeolite was added into $100 \mathrm{ml}$ as prepared $\mathrm{Na}_{2} \mathrm{SO}_{4}$ aqueous solution in a $200 \mathrm{ml}$ triangular flask. Then, continuously shaking $(100 \mathrm{rpm})$ of the triangular flasks were carried out in a shaker with water bath at $25^{\circ} \mathrm{C}$ for $24 \mathrm{~h}$.

\section{Anaerobic digestion experiment}

In the previous experiment, we found that both the methane yield and COD removal in the zeolite-fixed bioreactor are much higher than those in the bioreactor with sunken zeolite at the bottom. When zeolite was dropped into the bottom of the reactor, it is difficult to contact with the ammonium in the liquid, because the swine waste would cover on the surface of the adsorbents. In zeolite-fixed bioreactor, the zeolite was suspended in the upper layer of the digested liquid, where ammonium could easily be trapped by the adsorbent. Therefore, in this present study, the zeolite was contained in a porous bag and suspended in the digested liquid, rather than directly dispersed in the bioreactor.

A number of Duran bottles ( $300 \mathrm{ml}$, SIBATA) with silicon rubbers were used as bioreactors in this study. The methane fermentation experiments were performed in two groups of bioreactors: zeolite-fixed bioreactors and bioreactors without zeolite as the control. The zeolitefixed bioreactor was developed by hanging zeolite A- 3 fixed in a porous nylon bag (pore diameter: $3 \mathrm{~mm}$ ) in the Duran bottle. The schematic of zeolite-fixed bioreactor was shown in Figure 1. In the fermentation experiments, $200 \mathrm{ml}$ of diluted swine waste including $25 \%(\mathrm{w} / \mathrm{w})$ digested sludge was added into each bioreactor. After that, nitrogen flush was used to keep an anaerobic condition in the bioreactors. Then, the methane fermentation of piggery wastes was carried out in a batch mode at $35^{\circ} \mathrm{C}$ for 33 days. The biogas was collected using $50 \mathrm{ml}$ plastic syringes, and the volume was read directly using the scale on the syringe. Each group of experiments was performed in duplicate.

\section{Analytical methods}

The gas composition was detected by a gas chromatography (GC$8 \mathrm{~A}$, SHIMAZU, Japan) using a machine equipped with a thermal conductivity detector $\left(80^{\circ} \mathrm{C}\right)$ and a Porapak-Q column $\left(60^{\circ} \mathrm{C}\right)$. Nitrogen was used as the carrier gas. COD, TS, VS, and TN were detected according to standard methods [21], and $\mathrm{pH}$ was determined using a $\mathrm{pH}$ meter (TES 1380). The amount of ammonium nitrogen was measured by an ion meter (Ti 9001, Toyo Chemical Laboratories Co., Ltd.). The activity of microorganisms was indicated by ATP analysis using a BacTiter-Glo ${ }^{\text {tw }}$ Microbial Cell Viability Assay (Promega, USA). Morphological features of microorganisms immobilized on the zeolite after anaerobic digestion was observed using a scanning electron microscope (SEM) (JSM-6330F, JEOL, Japan).

\section{Results and Discussion}

\section{Ammonium adsorption on zeolite A-3}

Adsorption kinetic analyses: Prior to batch adsorption equilibrium studies, it is essential to confirm the equilibrium contact time required for the ammonium adsorption. Adsorption kinetic model is required for surveying the mechanism of adsorption. Several models have been utilized for the adsorption kinetic analyses. The most well-known models are Lagergren's pseudo-first-order and Ho's pseudo-second- 
Citation: Yu C, Li D, Wang Q, Zhang Z, Yang Y (2014) Improving Anaerobic Methane Production from Ammonium-rich Piggery Waste in a Zeolite-fixed Bioreactor and Evaluation of Ammonium Adsorbed on Zeolite A-3 as Fertilizer. Int J Waste Resources 4: 160. doi: $10.4172 / 2252-5211.1000160$

Page 3 of 8

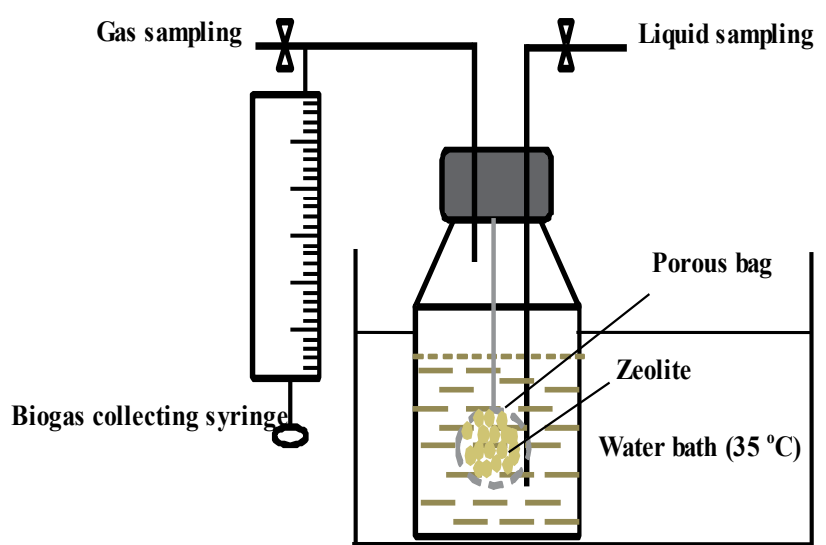

Figure 1: Schematic diagram of the zeolite-fixed bioreactor.

order. In order to assess the adsorption process of ammonium on the zeolite A-3, the above two models were applied to analyze the obtained experimental data under initial ammonium concentrations of $5000 \mathrm{mg}$ $\mathrm{l}^{-1}$, adsorbent loading rate of $10 \mathrm{~g} \mathrm{l}^{-1}$ and contact time from 0 to $24 \mathrm{~h}$. The integration of the pseudo-first-order kinetic equation is expressed as [22]:

$$
\log \left(q_{e}-q_{t}\right)=\log q_{e}-\frac{k_{1}}{2.303} t
$$

The integration of the pseudo-second-order model can be described by the following equation:

$$
\frac{t}{q_{t}}=\frac{1}{k_{2} q_{e}^{2}}+\frac{1}{q_{e}}
$$

where $\mathrm{k}_{1}$ is the pseudo-first-order rate constant $\left(\min ^{-1}\right), \mathrm{k}_{2}$ is the pseudo-second-order rate constant $\left(\mathrm{g} \mathrm{min}^{-1} \mathrm{mg}^{-1}\right), \mathrm{q}_{\mathrm{t}}$ is the amount of ammonium nitrogen adsorbed at time $\mathrm{t}\left(\mathrm{mg} \mathrm{g}^{-1}\right), \mathrm{q}_{\mathrm{e}}$ is the adsorption capacity at equilibrium $\left(\mathrm{mg} \mathrm{g}^{-1}\right)$, and $\mathrm{t}$ is the contact time ( $\left.\mathrm{min}\right)$.

The regressed curves and the correlation coefficients for the pseudofirst-order and the pseudo-second-order were shown in Figures 2A and $2 \mathrm{~B}$ and Table 1 , respectively. With regard to the pseudo-first-order model, the correlation coefficient was relatively low $\left(\mathrm{R}^{2}=0.9047\right)$, and the experimental adsorbed masses $\left(78.83 \mathrm{mg} \mathrm{g}^{-1}\right)$ was much higher than the theoretical value ( $\left.34.04 \mathrm{mg} \mathrm{g}^{-1}\right)$ at the equilibrium time. These results indicated a bad fit between the model and the experimental data; therefore, the adsorption of ammonium on zeolite A-3 was not compliant with the pseudo-first-order reaction.

For the pseudo-second-order model, the correlation coefficient $\left(\mathrm{R}^{2}\right.$ $=0.987)$ was much higher than that of the pseudo-first-order model $\left(\mathrm{R}^{2}\right.$ $=0.905)$, and no obvious distinct occurred between the experimental $\left(78.83 \mathrm{mg} \mathrm{g}^{-1}\right)$ and the theoretical adsorption capacity $\left(77.52 \mathrm{mg} \mathrm{g}^{-1}\right)$ at equilibrium. The good accordance between the experimental data and the pseudo-second-order kinetic model showed that the adsorption of ammonium on the zeolite A-3 was well described by the pseudosecond-order kinetic model. As a result, this adsorption could be dominated by a chemical process, mainly ion exchange, which was in accordance with the results obtained by many other researches $[12,23]$.

Adsorption isotherms: Adsorption isotherms are essential to describe how adsorbate masses will interact with adsorbent media and are useful to optimize the use of media as adsorbents. Therefore, empirical equations such as Langmuir and Freundlich isotherm models are important for investigating the adsorption mechanism. The linearized forms of Langmuir and Freundlich isotherms were applied to analyze the adsorption process under initial ammonium concentrations ranging from 1000 to $5000 \mathrm{mg} \mathrm{l}^{-1}$, adsorbent loading rate of $10 \mathrm{gl}^{-1}$ and contact time of $24 \mathrm{~h}$.

The Langmuir model assumes only one solute molecule per site, and also assumes a fixed number of sites. The linear form of the Langmuir isotherm equation can be expressed as followings [22]:

$$
\frac{C_{e}}{q_{e}}=\frac{1}{q_{m}}+\frac{C_{e}}{q_{m}}
$$

Freundlich isotherm assumes that the uptakes of adsorbate occur on a heterogeneous surface by multilayer adsorption and the amount of adsorbate adsorbed increases infinitely with an increase in concentration. The linear forms of the Freundlich isotherm equation is given as:

$\mathrm{h} q_{e}=\mathrm{h} k_{f}+\frac{1}{n} \mathrm{~h} C_{e}$

where $C_{e}$ is the liquid phase concentration of the ammonium nitrogen at equilibrium $\left(\mathrm{mg} \mathrm{l}^{-1}\right), \mathrm{q}_{e}$ is the amount of ammonium nitrogen adsorbed on the ceramic adsorbent at equilibrium $\left(\mathrm{mg} \mathrm{g}^{-1}\right)$, $\mathrm{q}_{\mathrm{m}}$ is the maximum adsorption capacity $\left(\mathrm{mg} \mathrm{g}^{-1}\right), \mathrm{b}$ is the Langmuir constant related to the adsorption energy $\left(\mathrm{mg}^{-1}\right), \mathrm{K}_{\mathrm{f}}\left(\mathrm{mg}^{1-1 / \mathrm{n}} \mathrm{l}^{1 / \mathrm{n}} \mathrm{g}^{-1}\right)$ is the Freundlich isotherm model constant indicating the adsorption capacity of the adsorbent, and $1 / \mathrm{n}$ is an empirical parameter related to the intensity of adsorption, which varies with the heterogeneity of the material [14]. The plot of $\ln q_{e}$ versus $\ln C_{e}$ for the adsorption of ammonium nitrogen onto the zeolite A-3 was employed to generate
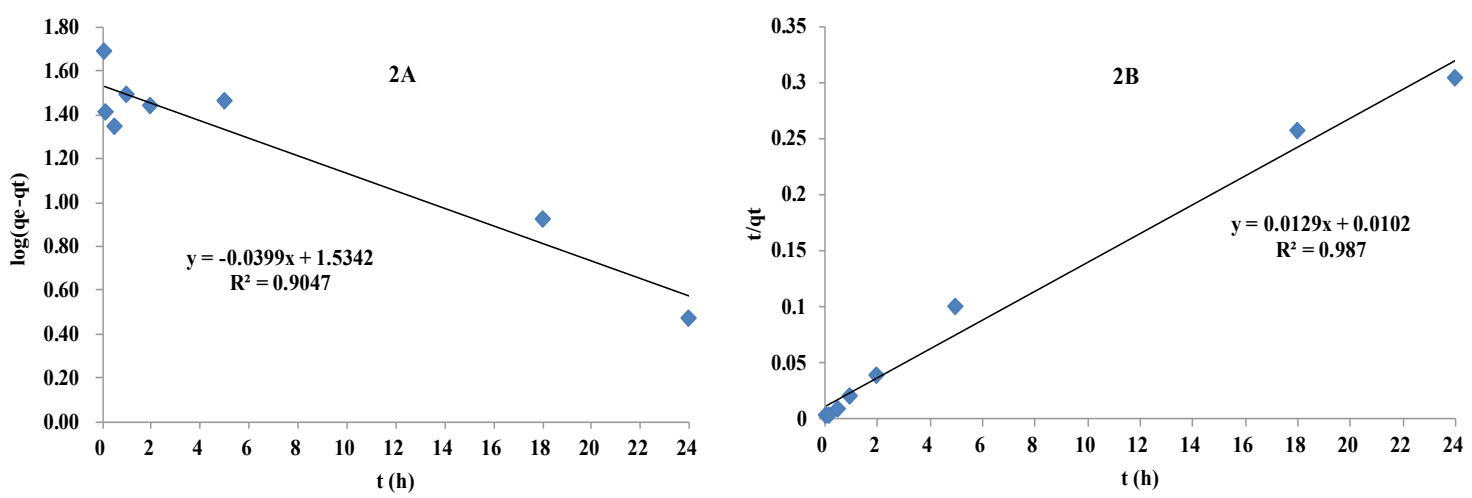

Figure 2: Kinetic Plots of ammonium adsorption on zeolite A-3: (A) pseudo-first-order kinetic model and (B) pseudo-second-order kinetic model. 
Citation: Yu C, Li D, Wang Q, Zhang Z, Yang Y (2014) Improving Anaerobic Methane Production from Ammonium-rich Piggery Waste in a Zeolite-fixed Bioreactor and Evaluation of Ammonium Adsorbed on Zeolite A-3 as Fertilizer. Int J Waste Resources 4: 160. doi: $10.4172 / 2252-5211.1000160$

Page 4 of 8

\begin{tabular}{|c|c|c|c|c|c|}
\hline \multicolumn{2}{|c|}{ Pseudo-first-order model } & \multicolumn{3}{c|}{ Pseudo-second-order model } \\
\hline $\mathrm{K}_{1}\left(\mathrm{~min}^{-1}\right)$ & $\mathrm{q}_{\mathrm{e}}\left(\mathrm{mg} \mathrm{g}^{-1}\right)$ & $\mathrm{R}^{2}$ & $\mathrm{~K}_{2}\left(\mathrm{~g} \mathrm{mg}^{-1} \mathrm{~min}^{-1}\right)$ & $\mathrm{q}_{\mathrm{e}}\left(\mathrm{mg} \mathrm{g}^{-1}\right)$ & $\mathrm{R}^{2}$ \\
\hline 0.09189 & 34.04 & 0.9047 & 0.016317 & 77.52 & 0.987 \\
\hline
\end{tabular}

Table 1: Pseudo-first-order model and Pseudo-second-order model constants for the ammonium adsorption on the zeolite A-3 adsorbent.

\begin{tabular}{|c|c|c|c|c|c|}
\hline \multicolumn{3}{|c|}{ Langmuir isotherm } & \multicolumn{3}{c|}{ Freundlich isotherm } \\
\hline $\mathrm{b}\left(\mathrm{L} \mathrm{mg}^{-1}\right)$ & $\mathrm{q}_{\mathrm{m}}\left(\mathrm{mg} \mathrm{g}^{-1}\right)$ & $\mathrm{R}^{2}$ & $\mathrm{~K}_{\mathrm{f}} \mathrm{mg}^{1-1 / n} \mathrm{~L}^{1 / n} \mathrm{~g}^{-1)}$ & $1 / \mathrm{n}$ & $\mathrm{R}^{2}$ \\
\hline 0.000348 & 84.03 & 0.9863 & 0.243781 & 0.6464 & 0.9846 \\
\hline
\end{tabular}

Table 2: Langmuir isotherm and Freundlich isotherm constants for the ammonium adsorption on the zeolite A-3 adsorbent.

the intercept value of $\mathrm{K}_{\mathrm{f}}$ and the slope of $1 / \mathrm{n}$.

The fitted curves for the Langmuir and Freundlich isotherms were shown in Figures $3 \mathrm{~A}$ and $3 \mathrm{~B}$, and the isotherm parameters for the adsorption of ammonium nitrogen onto the zeolite A-3 were listed in Table 2. It can be seen that both Langmuir and Freundlich model were applicable for the adsorption of ammonium on the zeolite A-3, according to the high values of the regression correlation coefficients $\left(\mathrm{R}^{2}>0.98\right)$. The similar result was reported by Halim et al., 2010 [24], who compared the ammonia adsorption on zeolite, activated carbon and composite materials in the treatment of landfill leachate. The good compliance to Langmuir and Freundlich isotherms showed that the ammonium removal by zeolite A-3 via both the cation exchange and physical adsorption mechanism. The $\mathrm{q}_{\mathrm{m}}$ of $84.03 \mathrm{mg} \mathrm{g}^{-1}$ calculated by the Langmuir model was higher than the measured value $(78.83 \mathrm{mg}$ $\left.\mathrm{g}^{-1}\right)$. The values of the empirical parameter $1 / \mathrm{n}$ lying between $0.1<1 / \mathrm{n}$ $<1$ indicated favorable adsorption for ammonium [22]. The $1 / \mathrm{n}$ value (0.6464) in the present study was lower than 1 , which represented favorable removal conditions.

\section{Ammonium desorption from saturated zeolite A-3}

Sodium sulfate $\left(\mathrm{Na}_{2} \mathrm{SO}_{4}\right)$ solution was used for ammonium desorption from saturated zeolite A-3, due to the advantages of nitrogen recovery in the form of ammonium sulfate $\left(\left(\mathrm{NH}_{4}\right)_{2} \mathrm{SO}_{4}\right)$ which is a nice nitrogenous fertilizer and zeolite regeneration. Figure $4 \mathrm{~A}$ shows the efficiency of ammonium desorption from zeolite A-3 and effluent $\mathrm{NH}_{4}{ }^{+} \mathrm{N}$ concentration in the bulk solution. Both the desorption efficiency of ammonium and the effluent $\mathrm{NH}_{4}^{+}-\mathrm{N}$ concentration in the bulk solution increased with reaction time and gradually reached equilibrium after 20 hours. The maximum desorption efficiency (38.2\%) and highest effluent $\mathrm{NH}_{4}^{+}$- $\mathrm{N}$ concentration $\left(76.4 \mathrm{mg} \mathrm{l}^{-1}\right)$ were obtained under the equilibrium state.

Desorption kinetic of $\mathrm{NH}_{4}^{+}$can be described by a first-order reversible mechanism [25], which is expressed as:

$$
C_{t}=C_{e}\left(1-e^{-\left(k_{1}+k_{-1}\right) * t}\right)
$$

where, $\mathrm{C}_{\mathrm{e}}$ and $\mathrm{C}_{\mathrm{t}}\left(\mathrm{mg} \mathrm{l}^{-1}\right)$ are the time-dependent concentration of the dissolved $\mathrm{NH}_{4}^{+}$at equilibrium and time $\mathrm{t}(\mathrm{h}) ; \mathrm{k}_{1}$ and $\mathrm{k}_{-1}\left(\mathrm{~h}^{-1}\right)$ are the adsorption and desorption rate constants, respectively. Its logarithm form can be given as Eq. (6).

$$
\text { h } \frac{C_{e}-C_{t}}{C_{e}}=-\left(k_{1}+k_{-1}\right) * t
$$

The chemical response time $\left(\tau_{\text {resp }}\right)$ for a first-order reversible reaction is:

$$
\tau_{\text {resp }}=\frac{1}{\left(k_{1}+k_{-1}\right)}
$$

The kinetic plot of $\ln \left(\left(\mathrm{C}_{\mathrm{e}}-\mathrm{C}_{\mathrm{t}}\right) / \mathrm{C}_{\mathrm{e}}\right)$ versus $\mathrm{t}$ of ammonium desorption was illustrated in Figure 4B. The high linear regression coefficient $\left(\mathrm{R}^{2}=\right.$ 0.982) indicated that desorption of ammonium from saturated zeolite A-3 well fits the first-order reversible reaction kinetic. Value for $\left(\mathrm{k}_{\mathrm{f}}\right.$ $+\mathrm{k}_{-1}$ ) obtained from the regression line was $0.179 \mathrm{~h}^{-1}$. The reaction constant $\left(\mathrm{k}_{1}+\mathrm{k}_{-1}\right)$ was used in Eq. (5) to predict desorption as a function of time. The calculated $\tau_{\text {resp }}$ was $5.59 \mathrm{~h}$.

\section{Performance of anaerobic digestion}

In a previous study [15], it was found that addition of natural zeolite (doses: 2-4 $\mathrm{g} \mathrm{l}^{-1}$ ) contributed to enhance the anaerobic digestion of piggery wastes with $\mathrm{NH}_{4}^{+}-\mathrm{N}$ concentration of $410 \mathrm{mg} \mathrm{l}^{-1}$ by reducing the ammonium inhibitory. In this present study, the $\mathrm{NH}_{4}^{+}-\mathrm{N}$ concentration of ammonium-rich piggery waste was as high as $3770 \mathrm{mg}$ $\mathrm{l}^{-1}$, which is approximately 9 -fold of that in the previous study. Thus, to obtain an optimum addition of zeolite A-3 for methane fermentation of ammonium-rich piggery wastes, the dosages loading rates of $10 \mathrm{~g}$ $\mathrm{l}^{-1}$ and $30 \mathrm{~g} \mathrm{l}^{-1}$ were used in the zeolite-fixed bioreactors. The adjusted piggery wastes with an initial ammonium nitrogen concentration of $3770 \mathrm{mg} \mathrm{l}^{-1}$ fed to each bioreactor. Ammonium inhibition has occurred above $\mathrm{pH} 7.4$ within the ammonium nitrogen concentration range of $1500-3000 \mathrm{mg} \mathrm{l}^{-1}$ during the anaerobic digestion process [3].

Figure $5 \mathrm{~A}$ shows that the startup period for anaerobic digestion was 13 days and 20 days in the zeolite-fixed bioreactors and the control bioreactor, respectively. Beginning from the $13^{\text {th }}$ day, methane production in $10 \mathrm{~g} \mathrm{l}^{-1}$ and $30 \mathrm{~g} \mathrm{l}^{-1}$ zeolite-fixed bioreactors increased gradually to the daily maximum of $583.5 \mathrm{ml} \mathrm{l}^{-1}$ and $543.3 \mathrm{ml} \mathrm{l}^{-1}$ on $21^{\text {th }}$ day, respectively. The corresponding methane concentration increased respectively from $72.5 \%$ to $87.3 \%$ and from $78.0 \%$ to $85.5 \%$ in these two bioreactors (Figure 5B). After that, the daily methane yield decreased gradually, whereas the methane concentration maintained at approximately $80 \%$ until the end of the digestion process. According to methane production and concentration during the first 20 days (Figures $5 \mathrm{~A}$ and $5 \mathrm{~B}$ ), the zeolite-fixed bioreactors showed better performance than the control.

Above results indicates that the zeolite-fixed bioreactor is effective for improving methane production in anaerobic digestion of ammonium-rich piggery wastes. Because inhibitory ammonium in the anaerobic digestion of piggery wastes was partially removed by the zeolite, the $\mathrm{NH}_{4}^{+}-\mathrm{N}$ levels in $10 \mathrm{~g} \mathrm{l}^{-1}$ and $30 \mathrm{~g} \mathrm{l}^{-1}$ zeolite-fixed bioreactors decreased respectively from 3770 to 3050 and $2958 \mathrm{mg} \mathrm{l}^{-1}$ during the first 4 day (Figure $5 \mathrm{C}$ ). However, the $\mathrm{NH}_{4}{ }^{+} \mathrm{N}$ level in the control bioreactor increased to $3896 \mathrm{mg} \mathrm{l}^{-1}$ on the $4^{\text {th }}$ day. The zeolite suspended in the upper layer of the digested liquid, where ammonium could easily be removed by the adsorbent. The ammonium concentration increased during the anaerobic digestion process, because ammonia is produced by the biological degradation of the nitrogenous matter [26]. After the $4^{\text {th }}$ day, the ammonium concentration in the zeolite-fixed bioreactors increased gradually. At the end of methane fermentation experiment which lasted for 33 days, the total $\mathrm{NH}_{4}^{+}-\mathrm{N}$ concentration in the zeolitefixed bioreactors $\left(10 \mathrm{~g} \mathrm{l}^{-1}, 30 \mathrm{~g} \mathrm{l}^{-1}\right)$ and the control bioreactor increased to 3904,3757 and $4940 \mathrm{mg} / \mathrm{l}$, respectively (Figure 5C).

Overall, the $\mathrm{pH}$ value in the three bioreactors was between 7.0 and 8.1 and thus fulfilled the favorable $\mathrm{pH}$ level for methane fermentation (Figure 5D). In the zeolite-fixed bioreactors, the $\mathrm{pH}$ level decreased 
Citation: Yu C, Li D, Wang Q, Zhang Z, Yang Y (2014) Improving Anaerobic Methane Production from Ammonium-rich Piggery Waste in a Zeolite-fixed Bioreactor and Evaluation of Ammonium Adsorbed on Zeolite A-3 as Fertilizer. Int J Waste Resources 4: 160. doi: $10.4172 / 2252-5211.1000160$
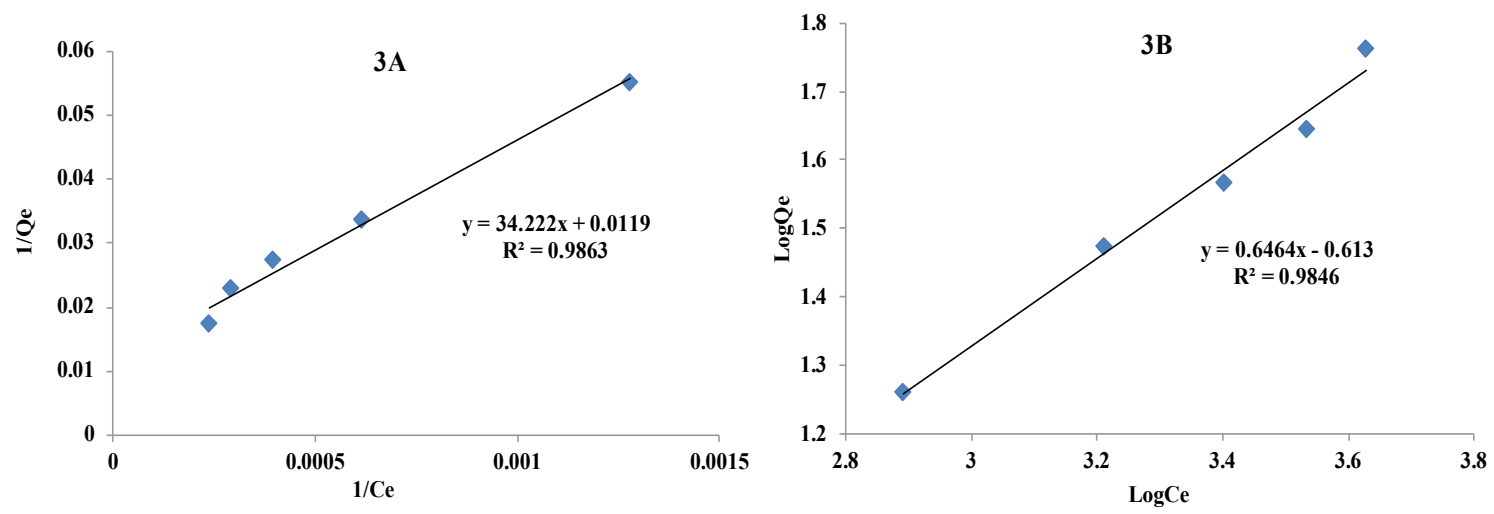

Figure 3: Ammonium adsorption isotherms on zeolite A-3: (A) Langmuir isotherm model and (B) Freundlich isotherm model.
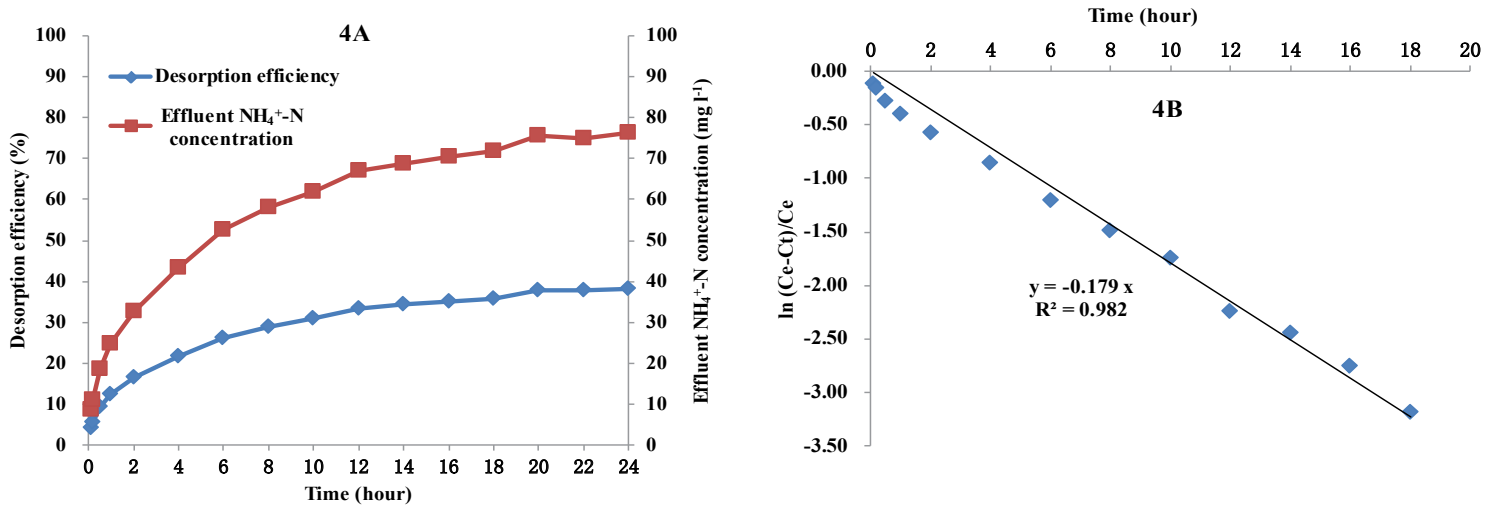

Figure 4: (A) The efficiency of ammonium desorption from zeolite A-3 and effluent $\mathrm{NH}_{4}{ }^{+}-\mathrm{N}$ concentration in the $\mathrm{Na}_{2} \mathrm{SO}_{4}$ solution, and (B) kinetic plots of ammonium desorption from the saturated zeolite $\mathrm{A}-3$.
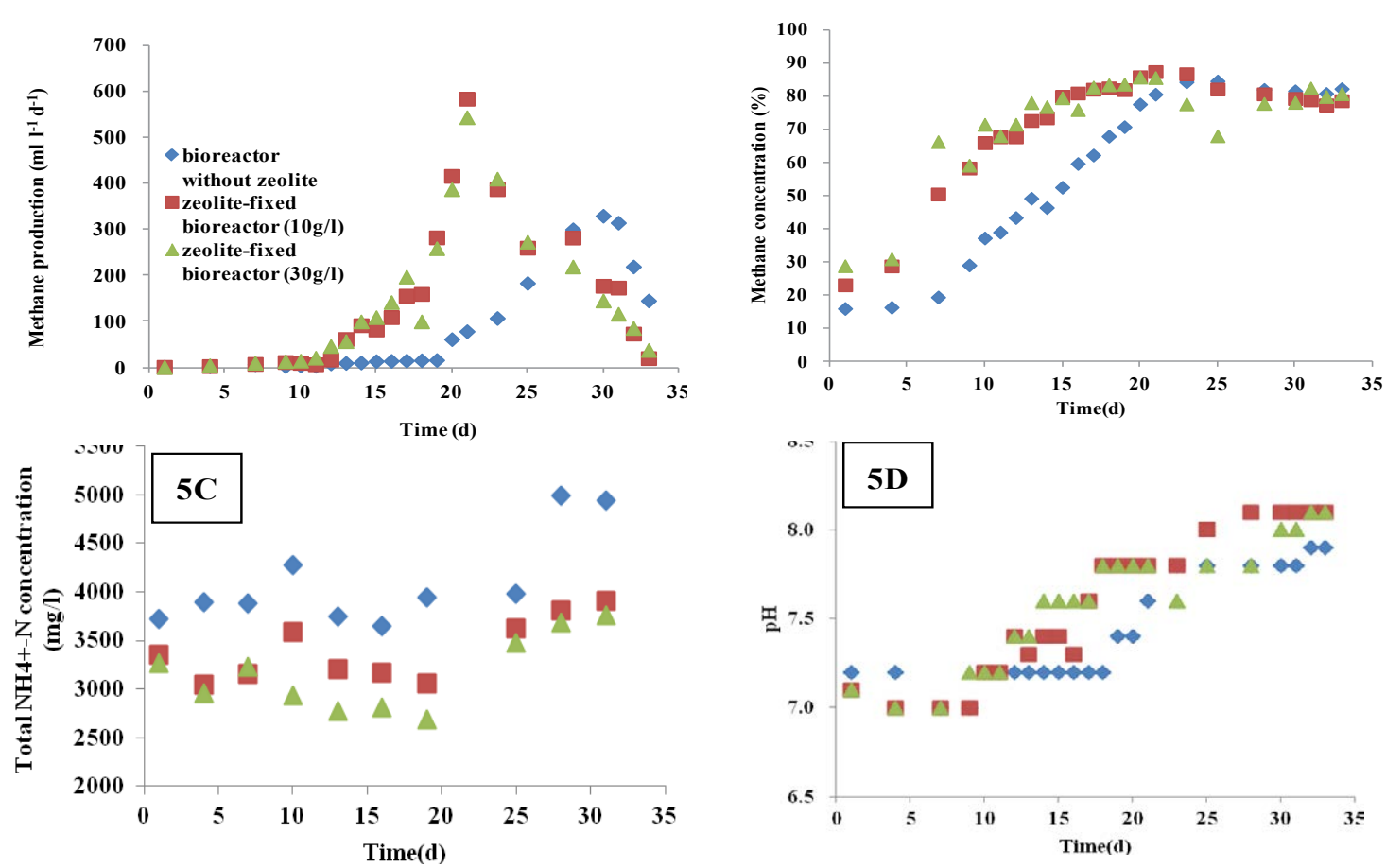

Figure 5: The performance of the zeolite-fixed bioreactors and bioreactor without zeolite as control for the anaerobic digestion of piggery wastes during the experiment: (A) methane production; (B) methane concentration; (C) ammonium nitrogen concentration and (D) $\mathrm{pH}$ value. 
Citation: Yu C, Li D, Wang Q, Zhang Z, Yang Y (2014) Improving Anaerobic Methane Production from Ammonium-rich Piggery Waste in a Zeolite-fixed Bioreactor and Evaluation of Ammonium Adsorbed on Zeolite A-3 as Fertilizer. Int J Waste Resources 4: 160. doi: $10.4172 / 2252-5211.1000160$

Page 6 of 8

slightly (from 7.1 to 7.0 ) during the startup period, because of the production of volatile fatty acid (VFA). Beginning on the $15^{\text {th }}$ day, the $\mathrm{pH}$ level gradually increased to 8.1 . Then it remained at 8.1 until the end of the digestion process. The increase in $\mathrm{pH}$ can be explained by the increasing of ammonium concentration and the biodegradation of VFA into methane. The $\mathrm{pH}$ level in the control bioreactor remained constant until day 18 and then increased to 7.9 on day 33 . This $\mathrm{pH}$ variation trend is consistent with that of methane production.

The $10 \mathrm{~g} \mathrm{l}^{-1}$ and $30 \mathrm{~g} \mathrm{l}^{-1}$ zeolite-fixed bioreactors showed similar trend of methane concentration and methane yield. Nevertheless, from the viewpoint of reducing mass transfer resistance and economic cost in the zeolite-fixed bioreactor, the optimum addition loading rate of zeolite was $10 \mathrm{~g} \mathrm{l}^{-1}$ in this study.

\section{Microorganism activity}

Generally, the quantity and activity of the microorganisms in a bioreactor are two conclusive parameters [27]. ATP is an indicator of metabolically active cells and an index of microbial density, which has been shown to reflect the microorganism activity in the anaerobic digestion [28]. In this study, ATP concentration was examined on the surface of the zeolite in the zeolite-fixed bioreactor, and in the liquid from all the bioreactors at the end of the digestion experiment. The similar ATP values obtained in the liquid phase of zeolite-fixed bioreactor and control bioreactor were 0.026 and $0.023 \mu \mathrm{mol} \mathrm{l}^{-1}$, respectively. However, the ATP concentration $\left(0.25 \mu \mathrm{mol} \mathrm{l}^{-1}\right)$ on the surface of the zeolite is much higher than that in the liquid phase in the zeolite-fixed bioreactor. This indicated that the high activity levels of the immobilized microorganisms on the zeolite surface, which could be understood as pointing that the fixed zeolite is a stable and suitable carrier for microorganisms, and most of them propagated on the surface of fixed zeolite. A number of microbes assembled on the surface of fixed zeolite (Figure 6B) resulted to the high concentration of ATP. The distribution of microbes in the liquid phase and on the surface of the support materials were about $5 \%$ and $95 \%$, respectively [29].

On the other hand, the surface morphology of the zeolite A-3 before and after the anaerobic digestion process were observed by SEM at a magnification of $6000 \times$. As illustrated in Figure 6A, the zeolite A-3 shows a porous structure and is covered with fractures. After anaerobic digestion the porous surface of zeolite was colonized subsequently by a great deal of methanogens (Figure 6B). This phenomenon confirmed the immobilization of microorganisms on the zeolite surface in the zeolite-fixed bioreactor.

In the anaerobic digestion of ammonium-rich piggery wastes, it has been found that free ammonia $\left(\mathrm{NH}_{3}\right)$ is the active form causing ammonia inhibition. The high concentration of free ammonia is the major causes of digester upset or failure. However, the adsorption of ammonium on zeolite surface mainly via the approach of cation exchange. Ammonium ion $\left(\mathrm{NH}_{4}^{+}\right)$rather than $\mathrm{NH}_{3}$ was adsorbed on the surface of zeolite. The toxicity of ammonia on the zeolite surface is much lower than that in the digested liquid. Therefore, the microbes tend to grow on the surface of the fixed zeolite in order to avoid the potential toxicity of free ammonia in the liquid and utilize the nitrogen source on the zeolite surface. Integrating the results of ATP analysis and SEM observation, it can be concluded that immobilization of microorganisms can be well performed using zeolite A-3 as carrier material in the zeolite-fixed bioreactor for effectively mitigating ammonia inhibition, thereby enhance the microorganism activity.

Effectiveness of zeolite-fixed bioreactor for the anaerobic digestion of ammonium-rich piggery wastes

As shown in Figure 7, the total methane yield $\left(354.2 \mathrm{ml} \mathrm{g}^{-1}-\mathrm{VS}\right)$ and COD removal rate (75.37\%) in zeolite-fixed bioreactor are both higher than those in the control bioreactor $\left(146.4 \mathrm{ml} \mathrm{g}^{-1}\right.$-VS and $35.10 \%)$. The methane yields are lower than the theoretical value (516 $\mathrm{ml} \mathrm{g}^{-1}$-VS) for piggery wastes [30]. However, the theoretical value is based on the assumption that all of the carbon substrate transformed into methane, a fraction of the substrate is in fact used to synthesize bacterial mass [31]. In addition, the quite high initial concentrations of $\mathrm{NH}_{4}^{+}-\mathrm{N}$ and COD are another factor that contributed to the lower actual methane yield for piggery wastes. Sánchez et al. [32] investigated piggery waste treatment using an upflow anaerobic sludge bed reactor (UASB) and an anaerobic fixed bed reactor (AFBR) at initial COD and $\mathrm{NH}_{4}^{+}-\mathrm{N}$ concentrations less than 12600 and $650 \mathrm{mg} \mathrm{l}^{-1}$, respectively. Their study obtained $60 \%$ COD removal in the AFBR and $40 \%$ of that in UASB, respectively. Here, at much higher initial concentrations of COD $\left(76700 \mathrm{mg} \mathrm{l}^{-1}\right)$ and $\mathrm{NH}_{4}^{+}-\mathrm{N}\left(3770 \mathrm{mg} \mathrm{l}^{-1}\right)$, the COD removal rate reached as high as $75.37 \%$ in the zeolite-fixed bioreactor. This result indicated that the zeolite-fixed bioreactor developed in this study is effective for improving the methane production from ammoniumrich piggery wastes. In further research, the practical effectiveness of developed zeolite-fixed bioreactor should be determined by carrying out the continuous anaerobic digestion of ammonium-rich piggery wastes. Due to the easy replacement and regeneration of ammonium saturated zeolite, it can be expected that the zeolite-fixed bioreactor would be stable and sustainable in continuous anaerobic digestion.

\section{Evaluation of ammonium adsorbed on zeolite A-3 as fertilizer}

In general, the utilization efficiency of nitrogenous fertilizer in soil in developed countries could reach $50-70 \%$ (data is from the Food and Agricultural Organization), whereas that in most of the developing countries like China is only about 30\% [33]. That means most of the nitrogenous nutrient was lost when using for crop growth. Fortunately, the ammonium saturated zeolite can be directly utilized as fertilizer to effectively avoid this lost, because of its slow-release of nitrogenous nutrient into the soil [23]. Besides, the zeolite itself was considered as a soil enhancer due to its nutrient retention capacity for potassium and phosphorus [34]. In this study, the ammonium adsorption capacity of zeolite A-3 is $78.83 \mathrm{mg} \mathrm{NH}_{4}^{+}-\mathrm{N} \mathrm{g}^{-1}$-zeolite, which means that approximately $7.9 \%$ of the ammonium nitrogen was adsorbed on zeolite. Direct utilization of ammonium saturated zeolite as fertilizer shows great potential to decrease annual production of nitrogen fertilizer, thereby save fertilizer cost $\$ 0.20$ per acre-inch [35] and mitigate the environmental pollution.

On the other hand, from the viewpoint of regeneration and reuse of zeolite, desorption of ammonium from saturated zeolite is of great interest. In this present study, the regeneration of saturated zeolite A-3 was successfully achieved by desorption of ammonium into $\mathrm{Na}_{2} \mathrm{SO}_{4}$ aqueous solution. In addition, a nice nitrogenous fertilizer $\left(\left(\mathrm{NH}_{4}\right)_{2} \mathrm{SO}_{4}\right)$ was obtained as a by-product during the ammonium desorption process.

\section{Conclusions}

A zeolite-fixed bioreactor was developed to mitigate ammonia inhibition and enhance methane production in the anaerobic digestion of ammonium-rich piggery wastes. Adsorption of ammonium on zeolite A-3 is compliant with the pseudo-second-order kinetic model and fits well to both Langmuir and Freundlich isotherms. Using zeolitefixed bioreactor could decrease the startup period, enhanced methane yield and COD removal. Direct utilization of ammonium saturated zeolite as fertilizer could be great potential to increase the utilization 
Citation: Yu C, Li D, Wang Q, Zhang Z, Yang Y (2014) Improving Anaerobic Methane Production from Ammonium-rich Piggery Waste in a Zeolite-fixed Bioreactor and Evaluation of Ammonium Adsorbed on Zeolite A-3 as Fertilizer. Int J Waste Resources 4: 160. doi: $10.4172 / 2252-5211.1000160$
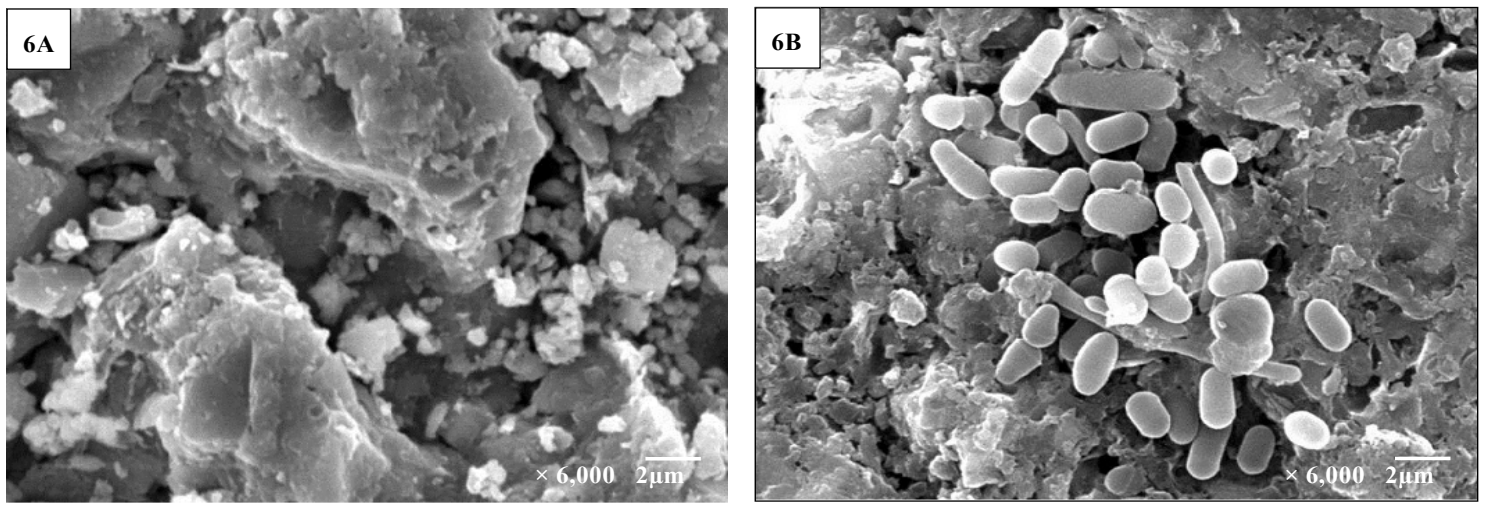

Figure 6: SEM images of (A) artificial zeolite A-3 and (B) microorganism immobilized zeolite A-3.

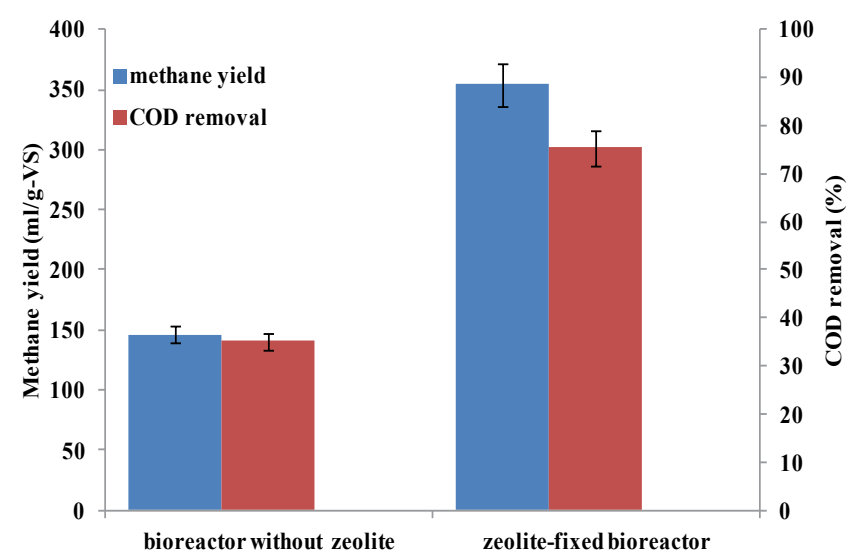

Figure 7: SMethane yield and COD removal in the zeolite-fixed bioreactor and bioreactor without zeolite as control.

efficiency of nitrogen fertilizer and decrease the environmental impact. Moreover, regeneration of zeolite A-3 using $\mathrm{Na}_{2} \mathrm{SO}_{4}$ solution also obtained a $\left(\mathrm{NH}_{4}\right)_{2} \mathrm{SO}_{4}$ by-product which is nice nitrogenous fertilizer.

\section{Acknowledgement}

The authors would like to thank the financial support from the Japan Society for the Promotion of Science (JSPS), Grants-in-Aid for Scientific Research (B) No. 25281048.

\section{References}

1. Wang Q, Yang Y, Yu C, Huang H, Kim M, et al. (2011) Study on a fixed zeolite bioreactor for anaerobic digestion of ammonium-rich swine wastes. Bioresour Technol 102: 7064-7068.

2. Hansen KH, Angelidaki I, Ahring BK (1998) Anaerobic digestion of swine manure: inhibition by ammonia. Water Res 32: 5-12.

3. Van Velsen AFM (1979) Adaptation of methanogenic sludge to high ammonia-nitrogen concentrations. Water Res 13: 995-999.

4. Gallert C, Bauer S, Winter J (1998) Effect of ammonia on the anaerobic degradation of protein by a mesophilic and thermophilic biowaste population Appl Microbiol Biotechnol 50: 495-501.

5. Hobson PN, Shaw BG (1976) Inhibition of methane production by Methanobacterium formicicum. Water Res 10: 849-852.

6. Yabu H, Sakai C, Fujiwara T, Nishio N, Nakashimada Y (2011) Thermophilic two-stage dry anaerobic digestion of model garbage with ammonia stripping. $J$ Biosci Bioeng 111: 312-319.

7. Wirthensohn $T$, Waeger $F$, Jelinek L, Fuchs W (2009) Ammonium removal from anaerobic digester effluent by ion exchange. Water Sci Technol 60: 201-210.
8. Uludag-Demirer S, Demirer GN, Chen S (2005) Ammonia removal from anaerobically digested dairy manure by struvite precipitation. Process Biochem 40: 3667-3674.

9. Calli B, Mertoglu B, Inanc B, Yenigun O (2005) Methanogenic diversity in anaerobic bioreactors under extremely high ammonia levels. Enzyme Microb Technol 37: 448-455.

10. Resch C, Wörl A, Waltenberger R, Braun R, Kirchmayr R (2011) Enhancement options for the utilisation of nitrogen rich animal by-products in anaerobic digestion. Bioresour Technol 102: 2503-2510.

11. Santhosh G, Venkatachalam S, Ninan KN, Sadhana R, Alwan S, et al. (2003) Adsorption of ammonium dinitramide (ADN) from aqueous solutions. 1. Adsorption on powdered activated charcoal. J Hazard Mater 98: 117-126.

12. Ugurlu M, Karaoglu MH (2011) Adsorption of ammonium from an aqueous solution by fly ash and sepiolite: Isotherm, kinetic and thermodynamic analysis. Microporous Mesoporous Mater 139: 173-178.

13. Baker HM, Massadeh AM, Younes HA (2009) Natural Jordanian zeolite: removal of heavy metal ions from water samples using column and batch methods. Environ Monit Assess 157: 319-330.

14. Huang $H$, Xiao X, Yan B, Yang L (2010) Ammonium removal from aqueous solutions by using natural Chinese (Chende) zeolite as adsorbent. J Hazard Mater 175: 247-252.

15. Milán Z, Sánchez E, Weiland P, Borja R, Martín A, et al. (2001) Influence of different natural zeolite concentrations on the anaerobic digestion of piggery waste. Bioresour Technol 80: 37-43.

16. Montalvo S, Díaz F, Guerrero L, Sánchez E, Borja R (2005) Effect of particle size and doses of zeolite addition on anaerobic digestion processes of synthetic and piggery wastes. Process biochem 40: 1475-1481.

17. Nikolaeva S, Sánchez E, Borja R, Travieso L, Weiland P, et al. (2002) Treatment of piggery waste by anaerobic fixed bed reactor and zeolite bed filter in a tropical climate: a pilot scale study. Process biochem 38: 405-409.

18. Kotsopoulos TA, Karamanlis X, Dotas D, Martzopoulos GG (2008) The impact of different natural zeolite concentrations on the methane production in hermophilic anaerobic digestion of pig waste. Biosyst Eng 99: 105-111.

19. Montalvo S, Guerrero L, Borja R, Travieso L, Sánchez E, et al. (2006) Use of natural zeolite at different doses and dosage procedures in batch and continuous anaerobic digestion of synthetic and swine wastes. Resour Conserv Recy 47: 26-41.

20. Demir A, Günay A, Debik E (2002) Ammonium removal from aqueous solution by ion-exchange using packed bed natural zeolite. Water SA 28: 329-335.

21. Eaton AD, Clesceri LS, Rice EW, Arnold E (2005) Standard methods for the examination of water and wastewater. American Public Health Association, USA.

22. Yusof AM, Keat LK, Ibrahim Z, Majid ZA, Nizam NA (2010) Kinetic and equilibrium studies of the removal of ammonium ions from aqueous solution by rice husk ash-synthesized zeolite $Y$ and powdered and granulated forms of mordenite. J Hazard Mater 174: 380-385.

23. Zhao Y, Yang Y, Yang S, Wang Q, Feng C, et al. (2013) Adsorption of high ammonium nitrogen from wastewater using a novel ceramic adsorbent and 
Citation: Yu C, Li D, Wang Q, Zhang Z, Yang Y (2014) Improving Anaerobic Methane Production from Ammonium-rich Piggery Waste in a Zeolite-fixed Bioreactor and Evaluation of Ammonium Adsorbed on Zeolite A-3 as Fertilizer. Int J Waste Resources 4: 160. doi: $10.4172 / 2252-5211.1000160$

Page 8 of 8

the evaluation of the ammonium-adsorbed-ceramic as fertilizer. J Colloid Interface Sci 393: 264-270

24. Halim AA, Aziz HA, Johari MAM, Ariffin KS (2010) Comparison study of ammonia and COD adsorption on zeolite, activated carbon and composite materials in landfill leachate treatment. Desalination 262: 31-35.

25. Millward GE, Liu YP (2003) Modelling metal desorption kinetics in estuaries. Sci Total Environ 314-316: 613-23.

26. Kayhanian M (1999) Ammonia inhibition in high-solids biogasification: an overview and practical. Environ Technol 20: 355-365.

27. Chen $\mathrm{H}$ (2004) ATP content and biomass activity in sequential anaerobic/ aerobic reactors. J Zhejiang Univ Sci 5: 727-732

28. Chu CP, Lee DJ, Chang BV, You CH, Liao CS, et al. (2003) Anaerobic digestion of polyelectrolyte flocculated waste activated sludge. Chemosphere 53: 757-764.

29. Yang Y, Tsukahara K, Sawayama S (2008) Biodegradation and methane production from glycerol-containing synthetic wastes with fixed-bed bioreactor under mesophilic and thermophilic anaerobic conditions. Process Biochem 43: $362-367$

30. Moller HB, Sommer SG, Ahring BK (2004) Methane productivity of manure, straw and solid fractions of manure. Biomass Bioenergy 26: 485-495.

31. Angelidaki I, Ahring BK (2000) Methods for increasing the biogas potential from the recalcitrant organic matter contained in manure. Water Sci Technol 41: 189-194.

32. Sánchez E, Milán Z, Borja R, Weiland P, Rodriguez X (1995) Piggery waste treatment by anaerobic digestion and nutrient removal by ionic exchange. Resour Conserv Recy 15: 235-244.

33. Wu J, Pan X (2008) Study progress on nitrogen losses in paddy field. Sci technol 6: 117-124.

34. Xie Z, Wang X, Niu S, Tong Z, Sun B, Zhao F (2006) Zeolite and modified application as soil amendment. Crops 26: 142-144.

35. Lambert DK (1990) Risk considerations in the reduction of nitrogen fertilizer use in agricultural production. Western J Agric econ 15: 234-244. 